\title{
Automated method for iterative optimization of macromolecular crystallization screens
}

Daniel Wrapp; Harrison Jones; Morgan S.A. Gilman; Michael B. Battles; Sofia Sacerdote; Nianshuang Wang; Kasia B. Handing; Ellen Gualtieri; Peter D. Kwong; Jason

\author{
S. McLellan
}

Major technological advances have increased the throughput of macromolecular crystallography, however, in many cases the identification of favorable crystallization conditions remains the rate-limiting step. Here, we present an automated method for the optimization of crystallization screens that iteratively adjusts precipitant concentrations based on the results of previous crystallization trials. In this Iterative Screen Optimization (ISO) method, the outcome of each crystallization experiment is visualized and manually scored using the program RockMaker. The scores are then used to generate a new crystallization screen by adjusting the precipitant concentrations of each reservoir solution to achieve a metastable macromolecular solution that favors crystal nucleation and growth. To facilitate the application of this method, we designed a crystallization screen comprising fifteen stock solutions of commercially available reagents that could be iteratively optimized using a Formulator liquid-handling device. We then assessed this screen and the ISO method on a set of six proteins that included several wellestablished crystallization standards. For all proteins evaluated, successive rounds of optimization produced a substantial increase in the number of crystallization hits. These results demonstrate that the ISO method is an efficient approach to maximizing the probability of obtaining crystals of a macromolecule from a limited set of reagents.

$\begin{array}{lll}\text { Daniel Wrapp } & \text { USA } & \text { Dartmouth College } \\ \text { Harrison Jones } & \text { USA } & \text { Dartmouth College } \\ \text { Morgan Gilman } & \text { USA } & \text { Dartmouth College } \\ \text { Michael Battles } & \text { USA } & \text { Dartmouth College } \\ \text { Sofia Sacerdote } & \text { USA } & \text { Dartmouth College } \\ \text { Nianshuang Wang } & \text { USA } & \text { Dartmouth College } \\ \text { Kasia Handing } & \text { USA } & \text { Formulatrix, Inc } \\ \text { Ellen Gualtieri } & \text { USA } & \text { Formulatrix, Inc } \\ \text { Peter Kwong } & \text { USA } & \text { Vaccine Research Center, National Institutes of Health } \\ \text { Jason McLellan } & \text { USA } & \text { Dartmouth College }\end{array}$

